\title{
ET HÅNDSKRIFTFUND I LÜBECK CA. 1620

\author{
OM DEN SPINKLE OVERLEVERING AF TO NORSKE \\ NATIONALKLENODIER
}

AF

KAREN SKOVGAARD-PETERSEN

Indledning

J 1880 udgav Gustav Storm en samling af norsk middelalderlatinsk

I litteratur i etbindsværket Monumenta historica Norvegia. Som den første tekst anbragte han en lille Norgeshistorie forfattet af en vis Theodericus med tilnavnet Monachus, munk. Dette vark er blandt det tidligste man kender af norsk latinlitteratur, skrevet omkring 1180. Det er bevaret for eftertiden i fire håndskrifter fra det 17. årh., og sammen med det optræeder i tre af disse håndskrifter et andet værk fra samme tid, nemlig den anonyme korstogsberetning Historia de Profectione Danorum in Hierosolymam, dvs. "Beretning om en dansk ekspedition til Jerusalem." På Storms tid regnedes dette værk for dansk, og det blev derfor ikke medtaget i Storms Monumenta-udgave, men i 1896 godtgjorde $\mathrm{Kr}$. Kaalund med stor sandsynlighed at forfatteren var nordmand.' Så hermed berigedes den norske middelalderlatin med endnu et værk. Det fik dog ikke desto mindre lov til at indgå i M. Cl. Gertz' udgave af kortere danske middelalderværker, Scriptores minores Historice Danicee medii avi II (1922).

Theoderiks Norgeshistorie og korstogsberetningen (herefter henholdsvis "Theoderik" og "Profectio") har altså fæelles overleveringshistorie, og det er den der er emnet for det følgende. Det er en historie som har både boghistoriske og idehistoriske aspekter. Selv om der er mange dunkle punkter, illustrerer den - så vidt den nu kan rekon-

\footnotetext{
' Kr. Kaalund: Kan Historia de profectione Danorum in terram sanctam regnes til Danmarks Litteratur?, Aarbgger for Nordisk Oldkyndighed og Historie, II. rk, bd. 11, 1896, s. 7996.
} 
strueres - hvordan forskellige interesser for fortiden til forskellige tider har gjort at de to middelalderkrøniker er blevet bevaret. ${ }^{2}$

Først et par ord mere om de to skrifter. De er ret korte (vel hver omkring 20 moderne tryksider) og begge vasentlige kilder til norsk - og delvis dansk - middelalderhistorie. Theoderiks værk skildrer Norges kongers historie fra Harald Hårfagers samling af Norge frem til ca. 1130. Det er dediceret til Ærkebiskop Øistein i Trondhjem (Nidaros) $\mathrm{og}$ må være affattet omkring 1180. Forfatteren havde efter alt at dømme studeret ved St. Victorklostret i Paris i anden halvdel af det 12. årh. I klostrets obituarier ("dødebøger") optrader faktisk hele to nordmaend ved navn Theoderik fra denne periode; begge havde tydeligvis opholdt sig i klostret. Den ene er Tore Gudmundarson, arkebiskop i Trondhjem 1206-14, den anden Tore, biskop i Hamar 1189/9096. Da Theoderiks Norgeshistorie ydermere opviser et lardomsapparat som tyder på at han har opholdt sig i Frankrig, og da særlig den markante teolog og leder af Victorklostrets skole Hugo af St. Victor (1096-1141) bliver genstand for hans lovprisning, er det højst sandsynligt at en af disse to mænd med navnet Tore, eller på latin Theodericus, der er omtalt i St. Victorklostrets obituarier, faktisk er historieskriveren. ${ }^{3}$

Forfatteren til korstogsberetningen har derimod ikke ladet sig identificere med nær samme sandsynlighed. Det har ikke skortet på forslag, men ingen har varet overbevisende. Det fremgår dog af beretningen at han var kannik og i en periode havde boet $\mathrm{i}$ Tønsberg $\mathrm{i}$ det sydligste Norge, og der er nappe tvivl om at han var norsk og at han tilhørte premonstratenserordnen.

Dateringen af skriftet er mindre usikker. Det skildrer en ekspedition til det hellige land, der blev organiseret på opfordring af pave Gregor VII efter at Jerusalem kom på muslimske hander i 1187. Det fremgår at ekspeditionen fandt sted 1191-92, og da forfatteren indledningsvis anfører at dette foregik "for nogle år siden," kan det dårligt vaere skrevet før 1195, måske 1194. Hvad den anden ende, dateringen ante quem, angår, må man formode at hele begivenheden har haft en vis aktuali-

\footnotetext{
"Narvarende artikel vil ikke gå ind på de filologiske sider af historien. De vil blive behandlet i den kommende udgave af korstogsberetningen De Profectione Danorum in Hierosolymam (2002/2003).

${ }^{3}$ Denne opdagelse gjorde A.O. Johnsen: Om Theodoricus og hans historia de antiquilate regam Norwagiensium, Oslo 1939. Jf. Lars Boje Mortensen: Passio Olaui, William of Jumièges, and Theodoricus Monachus, Symbolae Osloenses, 75, s. 165-189.
} 
tet, da forfatteren, som han selv siger, blev opfordret til at nedfæelde den på skrift af en fornem gejstlig," så beretningen er næppe skrevet mange år efter år 1200. Dette bekreftes af at Kong Sverre af Norge, Knud VI og biskop Absalon alle er omtalt uden antydning af at de ikke længere skulle være i live - og de døde alle tre i årene 1201-2.5

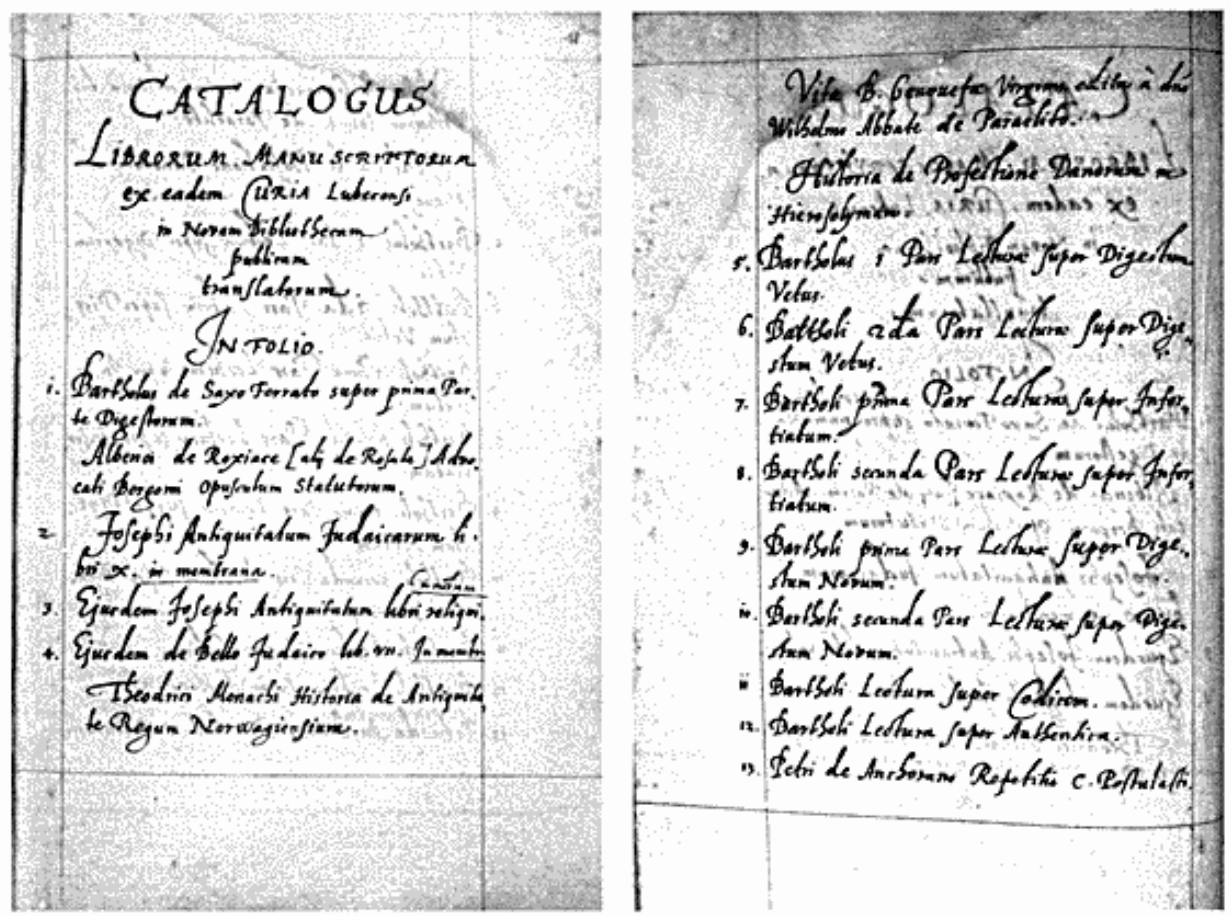

$\mathrm{I}$ årene 1620-22 udarbejdede Johann Kirchmann et katalog over bogbestanden i det nye Stadtbibliothek i Lübeck. På bl. $18 \mathrm{r}-\mathrm{v}$, som er afbildet her, begynder listen over hảndskrifter som biblioteket havde modtaget fra byrådet. Som nummer fire omtales håndskriftet der bl.a. indeholder Theoderik og Profectio. (Bibliothek der Hansestadt Lübeck, Ms Lub. fol 682). Jeg takker biblioteket for tilladelse til reproduktion og stor hjalpsomhed iøvrigt.

${ }^{4}$ Hvis identitet også er ukendt. Han tiltales indledningsvis som Reuerendo et diligendo Domino $K o g$ til sidst i skriftet henvender fortalleren sig til ham med ordene sanctitas uestra, deres Hellighed, så der er ikke tvivl om at der er tale om en højtstående gejstlig.

${ }^{3}$ Som påpeget af A.O. Johnsen i artiklen: Ny tolkning av Historia de Profectione Danorum in Hierosolymam i Frân medeltid till välfärdssamhälle. Nordiska historikermötet $i$ Uppsala 1974, Stockholm, s. 507-527. 


\section{Det middelalderlige håndskrift}

Vi bevæger os nu til det 17 . århundredes nordlige Tyskland, nærmere bestemt Lübeck. Her indrettedes der i årene omkring 1620 et nyt Stadtbibliothek. Bibliotekets første leder blev Johann Kirchmann, rektor ved Katharineum-gymnasiet i byen. Kirchmann, der levede fra 1575 til 1643, var en antikvarisk og kulturhistorisk orienteret forsker. I 1605 havde han således udgivet et væerk om romernes begravelsesskikke, $D e$ funeribus Romanorum (Hamborg), og i 1623 kunne han sende afhandlingen De annulis liber i trykken, der omhandlede brugen af ringe, ikke kun hos de gamle, grækerne og romerne, men også med udblik til andre folkeslag. Derudover kastede han sig, som vi skal se i det følgende, over norsk middelalderhistorie.

Blandt de bogsamlinger som dannede grundstammen i det nye bibliotek, var byrådets samling af trykte såvel som håndskrevne bøger. Herfra var der et håndskrift som særlig fangede Johann Kirchmanns opmærksomhed. I det katalog som han udarbejdede over bibliotekets bestand i 1622, beskriver han det således:

Ejusdem de Bello Judaico lib. vii.

Theodrici Monachi Historia de Antiquitate Regum Norwagiensium.

Vita B. Genouefe Virginis edita a domino Wilhelmo Abbate de Paraclito.

Historia de Profectione Danorum in Hierosolymam

("Samme forfatters værk om Den jødiske Krig i syv bøger.

Theoderik Munks beretning om de norske kongers historie.

Den hellige jomfru Genovefas liv, udgivet af Abbed Vilhelm af Ebelholt.

Beretning om en dansk ekspedition til Jerusalem").

Den "samme forfatter" Kirchmann her refererer til, er den jødiske historiker Josephus, der levede i det første årh. e. Kr. Betegnelsen "samme forfatter" refererer til det umiddelbart foregående håndskrift $\mathrm{i}$ Kirchmanns katalog, der ligeledes var et værk af Josephus. ${ }^{6}$

Håndskriftet indeholdt altså fire værker: Først kom Josephus' beretning (i dens latinske form, oversat i senantikken fra den oprindelige græske) om Den jødiske Krig, Bellum Judaicum, derefter fulgte Theo-

'Jeg takker Andrea Mielke, Bibliothek der Hansestadt Lübeck, for kopier fra Kirchmanns katalog samt andet materiale. 
deriks Norgeshistorie, så kom - tilsyneladende - et helgenvita om den senantikke helgeninde Genovefa, der her tilskrives abbed Vilhelm af Ebelholt, og til sidst korstogsberetningen De Profectione Danorum.

Dette håndskrift som Kirchmann fandt $\mathrm{og}$ hvis indhold han her har beskrevet, forsvandt igen i løbet af det 17. årh. Men fra Kirchmanns katalog kan vi altså se at det var et pergamenthåndskrift i folioformat, og at det indeholdt de fire næunte skrifter. Hvor og hvornår og i hvilken sammenhæeng håndskriftet blev til ved vi ikke, men på grundlag af Kirchmanns oplysninger kan man foretage nogle overvejelser.

Josephusteksten er langt den æeldste af de fire tekster i håndskriftet. De tre øvrige småskrifter er alle, formodentlig, forfattet i sidste halvdel af det 12. årh. eller begyndelsen af det 13. årh. Så enten er der tale om et ældre Josephushåndskrift hvori de tre tekster engang efter ca. 1200 er blevet føjet ind, eller også er hele håndskriftet produceret efter ca. 1200 .

Tilstedevarelsen af Theoderik og Profectio peger på at dette er foregået i et dansk eller norsk skriptorium. Det gør også den tredje af de små tekster, Genovefa-vita'et af abbed Vilhelm. Vilhelm var som bekendt en fransk victorinerkannik der i 1160erne forlod St. Genevièveklostret i Paris og kom til Danmark, hvor han en halv snes år senere grundlagde klostret Æbelholt. Nu kendes dette skrift ikke iøvrigt, heller ikke blot af omtale, men Vilhelm forfattede et andet skrift om den senantikke helgeninde Genovefa (Paris' skytshelgen), eller rettere om de relikvier som kannikerne i St. Genevièveklostret sad inde med. Det er en beretning om hvordan Sainte Genevièveklostrets kanniker i 1162 blev anklaget for at have forfalsket deres fornemste relikvie, Genevièves lig. ${ }^{7}$ Så en mulighed er at det er dette skrift der er tale om, på trods af betegnelsen vita, levnedsskildring. I et 15 . årh.s legendarium fra Genevièveklostret omtales Vilhelms relikvieskrift som en legenda, så det er tænkeligt at det også er dette værk der optrådte i det håndskrift Kirchmann fandt. ${ }^{8}$ Under alle omstzendigheder kan indlemmelsen af skriftet godt tale for at håndskriftet er blevet til i et victorinsk, Vilhelm-inspireret miljø. I samme retning peger Theoderiks

${ }^{7}$ Tractatus Beati Guillermi De reuelatione capitis et corporis beate Genouefe. Skriftet er udg. af M.Cl. Gertz i Vitae Sanctorum Danorum, 1908-1912, s. 378-382. Se også s. 85 i Ivan Boserup: En fransk-dansk brevsamling - og nogle danske diplomatarier, Levende Ord og Lysende Billeder. Den middelalderlige bogkultur i Danmark. Essays, red. Erik Petersen, 1999, s. $78-95$.

${ }^{8} \mathrm{Jeg}$ takker Ivan Boserup, Kgl. Bibl., for oplysningen. 
historie, for Theoderik havde som næunt med stor sandsynlighed studeret i det victorinske miljø i Paris i anden halvdel af det 12. årh.

Hovednummeret $\mathrm{i}$ håndskriftet har imidlertid varet den første tekst, nemlig Josephus' Bellum Judaicum. Den har vaeret langt den mest omfattende. Josephus' varker blev i senantikken oversat fra græsk til latin og i deres latinske form nød de stor popularitet i middelalderen. ${ }^{9}$ De var blandt de vigtigste patristiske historietekster. De omhandlede den jødiske historie i antikken og supplerede derved den bibelske historie, og blev faktisk brugt som kommentar til den. Ovenikøbet forenede Josephus (også ved sin person sådan som den fremtræeder i værkerne) den jødiske og den romerske historie. Hans Bellum Judaicum skildrer romermagten i det første årh. e. Kr. som overvældende og respektindgydende, hvad der harmonerede med den almindelige opfattelse i middelalderen af Romerrigets universelle dimensioner ved Kristi fødsel. Håndskriftet har altså varet indledt af et stort værk af universalhistorisk karakter efterfulgt af tre små varker af mere lokalhistorisk - dansk-norsk - indhold.

Hvad enten de tre småskrifter nu blev føjet til i slutningen af et aeldre Josephushåndskrift eller Josephushåndskriftet $\mathrm{i}$ sin helhed blev produceret i et dansk eller norsk victorinsk skriptorium, er det formodentlig sket i første del af det 13. årh. I hvert fald må alle de tre småskrifter have påkaldt sig størst interesse - og dermed mest sandsynlig have varet genstand for kopiering - $\mathrm{i}$ årtierne umiddelbart efter deres affattelse.

\section{Haindskriftets vej til Lübeck}

Efter alt at dømme var det også på grund af Josephusteksten at håndskriftet havnede i Lübeck, hvor Kirchmann så fandt det omkring 1620. Omtrent to århundreder tidligere, i første halvdel af det 15. årh., havde de italienske renæssancehumanister næret stærke forhåbninger om at gøre sensationelle håndskriftfund af klassiske tekster i Nordeuropa, herunder Skandinavien. Bl.a. ville et vedholdende rygte vide at der i Sorø befandt sig et håndskrift indeholdende hidtil ukendte dele af Livius' store værk om Roms historie (1. årh. f. Kr.). Gentagne håndskriftekspeditioner blev ivarksat, men Livius dukkede aldrig op. ${ }^{10}$

\footnotetext{
${ }^{9}$ Herom i Heinz Schreckenberg: Reseptionsgeschichtliche und texlkritische Untersuchungen zu Flavius Josephus, Leiden 1977.

${ }^{10}$ Se J. Sandys: History of Classical Scholarship, II, New York 1967, s. 24ff. 1. udg. 1903ff.
} 
En af de ekspeditioner man ved mest om, blev foretaget af den pavelige nuntius Marinus de Fregeno, der drog afsted i 1457. Hans ærinde var først og fremmest at samle penge til paverne Calixtus IIIs og Pius IIs tyrkerkrig, men desuden var han også en ivrig bogsamler. Hans ihærdighed på begge områder gav ham en meget dårlig presse blandt danske historikere $\mathrm{i}$ de følgende århundreder. Han sendte løbende penge indsamlet ved afladshandel til Rom, men lod også en del af sine skatte opbevare i Lübeck. I 1464 eller begyndelsen af 1465 drog han til Polen for at fortsætte sin virksomhed der. Nu faldt han imidlertid i unåde hos paven, hvem det var kommet for øre at han havde beholdt en del af det gods han havde indsamlet i Danmark, Norge og Sverige, og på pavens ordre blev hans gods i Lübeck konfiskeret."

Kong Christian I af Danmark mente sig nu også snydt for en del af Marinus' gods. Han sendte sin laege Engelbert Korner afsted for at beslaglægge noget af Marinus' gods i Lübeck. Og faktisk ved man fra samtidige dokumenter at Korner som en del af sin løn fra kongen modtog tre Josephushåndskrifter og et Augustinhåndskrift fra det konfiskerede Marinusgods - $o g$ at Korner derpå solgte dem til Lübecks råd for 89 lübske mark. ${ }^{12}$

Det var den tyske middelalderforsker Paul Lehmann som i 1930rne undersøgte Marinus' virksomhed som håndskriftsamler i Skandinavien. Han pegede på den sandsynlige forbindelse mellem Marinus og vores håndskrift og gav dermed en forklaring på at det var endt $\mathrm{i}$ Lübeck. ${ }^{13}$ Lehmanns tese støttes af at Johann Kirchmann i sit bibliotekskatalog angiver at vores Josephushåndskrift var et af tre Josephushåndskrifter hans bibliotek havde fået fra Lübecks råd, så der er næppe tvivl om at det var de tre Josephus'er Korner fik fra Marinus'

"Se Lübeck Ratschronik 1438-1482, I, Chroniken der deutschen Städte 30, Lübeck, Bd. 4, ed. Friedrich Bruns, Leipzig 1910, s. 372-373.

${ }^{12}$ Udgiveren af Lübeck Ratschronik (se note 11) Fr. Bruns citerer s. 373 brev fra Christian 1., hvori kongen erklaerer at have beslaglagt "etliker guder unde boke, namliken dre grote volumina Josephi gehetem und eyn kleyn volumen Augustinus de civitate Dei genomet ... de wii vort deme werdigen mester Engelbete Korner, unsem doctori unde phisico, in affkortinghe unde vormynneringe zines vordenden lones... overgeantwort unde gedan hebben, de welke bok de eerscreven mester Engelbert deme ersamen rade to Lubeke ... vor negenundeachtentich mark Lubesch recht unde redeliken hefft vorlofft." Lub. U. B. 10, Nr. 596. Jf. Paul Lehmann: Auf der Suche nach alten Texten in nordischen Bibliotheken, Zentralblatt für Bibliothekswesen, 54, 1937, 261-286 (her specielt s. 267).

1" Paul Lchmann (note 12), s. 261-286. 
konfiskerede gods - og heller ikke om at Marinus havde fundet dem i Skandinavien.

Et nærmere studium af Marinus' skandinaviske rejserute ville måske kunne være til hjælp i spørgsmålet om hvorfra håndskriftet kunne formodes at stamme. Han opholdt sig i begyndelsen af 1460erne i Sverige og Norge og blev også i denne periode kannik i Strängnäs. ${ }^{14}$ Danmark har han formentlig ligeledes besøgt, men foreløbig har hans spor ikke kunnet følges i detaljer.

Marinus' virksomhed skal som sagt ses i forbindelse med renæssancehumanisternes håndskriftjagt. Eller som den samtidige Chronica Slavorum siger om ham:

"Han havde blandt andet flere bøger, som han med list havde taget fra danskerne og svenskerne. Disse bøger skulle goterne efter sigende have taget fra byen Rom og omegn, da de plyndrede byen i 378 e. Kr."

(Habuit inter cetera plures libros, quos a Danis et Suecis argute abstulit. Hos credebantur Gothi abstulisse de urbe Romana et circumcirca, quando urbem devastarunt anno domini 378$)^{15}$

- de gotiske barbarer mistænktes, som det ses, for at have taget uvurderlige håndskrifter med sig nordpå i slutningen af det 4. årh. Marinus fandt ingen Livius. Men han fandt både Josephus og Augustin, og dem ville han have med tilbage til Italien. At der så befandt sig nogle uanselige middelalderlige krøniker i slutningen af det ene Josephushåndskrift har han formodentlig ikke heftet sig synderligt ved. Det var de antikke tekster der påkaldte sig renæssancehumanistens interesse.

\section{Johann Kirchmann og den danske regering}

Helt anderledes så Johann Kirchmann på sagen i 1620. For ham var sensationen de to dansk-norske krøniker. Josephusteksten var kendt og udkommet i talrige trykte udgaver (på latin udkom den allerede før 1500, på græsk første gang 1544). Genovefa-vitaet - eller, hvad det altså måske var, beretningen om hendes relikvier - har sikkert forekommet ham både historisk uinteressant og religiøst suspekt. Men han var over-

"Se Acta Pontificum, III, 1908 samt Diplomatarium Norvegium, 16, 17 og 21. Jf. Paul Lehmann (note 12), s. 267.

${ }^{15}$ Citeret efter Lübeck Ratschronik (note 11), s. 373. 
bevist om at disse to krøniker, hvis de virkelig hidtil var ukendte, udgjorde, som han skrev til en bekendt, en vidunderlig skat. ${ }^{16}$

Han besluttede sig for at foranstalte en udgave af de to skrifter, og det kom til at beskæftige ham de sidste tyve år af hans liv. Først måtte han imidlertid forvisse sig om at der virkelig var tale om hidtil ukendte værker. I 1624 kontaktede han den slesvig-holstenske kansler Theodor Busse $^{17}$ og gennem ham den lærde danske adelsmand Holger Rosenkrantz. ${ }^{18}$ Desuden har han åbenbart, også midt i 1620rne, henvendt sig til en tysk teolog ved enkedronning Sofies hof i Nykøbing Falster, Nic. Vismar, for Vismar forelagde i 1626 sagen for den kongelige historiograf Johannes Meursius ved Sorø Akademi og spurgte om han kendte noget til de værker. ${ }^{19}$ Ingen svarede positivt.

Kirchmann kastede sig entusiastisk over arbejdet med at kommentere og udgive. Han var klar over at dette kunne have kongens interesse. Og gennem sine forespørgsler håbede han, som han skrev til Busse, at sagen ville komme kongen for øre. Det gjorde den - og den vakte ganske rigtigt nysgerrighed. I marts 1625 skrev Christian 4. til sine rentemestre at "effersom nogle Fragmenta aff dansche historier schal findis til Lybeck, efftersom oss elschelige Doctori Arnisco derom schall were beuist, da wille wi i lige maade, at $i$ handler med den, som denum haffuer, om en billig forcering, som och i lige maade schulle forferdigis til trych". ${ }^{20}$

${ }^{16}$ Brev fra Kirchmann til T. Busse (se note 17 ).

"Brev fra Kirchmann til Busse 9.5.1625 udg. i Marquardi Gudii et Claudii Sarravii Senatoris Parisiensis Epistole una cum responsis. quibus accedunt ex Bibliotheca Gudiana clarissimorum $\mathcal{E}$ doctissimorum Virorum, qui duobus ultimis seculis floruerunt epistole ... curante Petro Burmanno, Leiden 1711, nr. 218. De relevante passager er også citeret $\mathrm{i}$ Bernhard Kirchmann's udgave af Theoderik og Profectio, Commentarii historici duo hactenus inediti, Amsterdam 1684, Forord til Læseren, og i Gustav Storms udgave af Theoderik, Monumenta historica Norvegia, 1880, nr. 1.

${ }^{18}$ Brev fra Kirchmann til Holger Rosenkrantz 20.7.1625, udg. i Kirchmann (note 17), Gude (note 17), og Storm (note 17). Brevet findes ogsâ i en håndskreven samling af Kirchmanns breve i Kgl. Bibl., NkS 614, 4to, II, no. 95.

${ }^{19}$ Brev fra Vismar til Johannes Meursius 30.7.1626, Meursius: Opera Omnia, 1741-63, $\mathrm{XI}$, no. 610. I den håndskrevne samling af Kirchmann's breve (note 18) var der et brev fra Vismar til Meursius skrevet midt i 1620rne, men de sider er desvaerre ikke laengere i håndskriftet.

${ }^{30}$ Missale til Rentemestrene fra Christian 4. 1.3.1625 udg. efter kopi i Konsistoriets Arkiv, 189, i H.F. Rørdam: Klavs Christoffersen Lyskanders Levned ..., 1868, s. 156. Se også Kancelliets Brevboger 1624-26, s. 347. 
Hvorfra Christian 4.s tyske læge Henning Arnisæus kan have fået oplysninger om Kirchmanns fund er ikke klart, men der kan næppe vare tvivl om at det faktisk var de to skrifter Christian 4. sigtede til med den noget løse betegnelse "nogle Fragmenta aff dansche Historier."

Kongens ønske om at få skrifterne skaffet til København og udgivet falder fint $i$ tråd med en hel række andre historiografiske initiativer taget af den danske regering i denne periode. Samme dag som Christian 4. skrev til rentemestrene angående de lübeckske fund, instruerede han universitetets professorer om at gennemse universitetsbibliotekets gemmer for historiske dokumenter og lade dem forfærdige til tryk. Dagen efter blev Jesper Brochmand i et kongebrev bedt om at foranstalte en ny udgave af Huitfeldts danmarkshistorie, og senere samme år blev professorerne anmodet af kongen om at treffe forberedelser til at fă udgivet Hans Svanings danmarkshistorie, der 45 år tidligere var blevet erklæret uværdig til trykning af universitetets professorer. $\mathrm{Og}$ sidst men ikke mindst lønnede den danske regering fra 1625 hele to historiografer, Johannes Pontanus og Johannes Meursius, med henblik på at kunne udsende en tidssvarende latinsk danmarkshistorie. ${ }^{.2}$

Der var kort sagt tale om en voldsom interesse fra den danske regerings side i at få udsendt danmarkshistoriske værker på tryk. Denne interesse skal nok for en stor del tilskrives Christian 4.s kansler Christen Friis, der i hele sin kanslerperiode var meget aktiv i promoveringen af den nationale historie. Men den akutte hektiske iver som kan noteres hos regeringen i midten af 1620rne udspringer formentlig også af Christian 4.s eget stigende engagement på den internationale scene, hvad der som bekendt førte til dansk deltagelse i den europæiske krig $\mathrm{i}$ årene 1626-29.

Det ser ikke ud til at rentemestrene faktisk henvendte sig til Kirchmann i Lübeck, sådan som kongen havde bedt dem om. Men regeringens interesse var stadig til stede, og i løbet af de to næste år indløb der også mere pracis viden om de lübeckske fund til regeringen i København. Man erfarede nu at Johann Kirchmann i Lübeck var ved at forberede en udgave af et skrift om norsk historie, og at Holger Rosen-

\footnotetext{
${ }^{21}$ Det blev foreslăet af Ole Degn i hans biografi over kansler Christen Friis: Christian 4.5 kansler, 1988 , s. 127.

${ }^{2 x}$ Narmere om de nationalhistoriografiske initiativer i Karen Skovgaard-Petersen: Historiography at the Court of Christian IV. Studies in the Latin Histories of Denmark by Johannes Pontanus and Johannes Meursius, 2002), isar kap. 2.
} 
krantz sad inde med viden herom. Så det var til ham Christian 4. i 1627 henvendte sig for at få nærmere besked om varkets indhold - og for at bede ham undersøge om det var blevet udgivet tidligere. ${ }^{23}$

Her sigtes åbenbart kun til Theoderiks norgeshistorie, historia regum Norvigiensium, som det omtales. Men alene den var nok til at påkalde sig regeringens interesse. Norsk historie var tydeligvis en del af den nationale historie, som regeringen i disse år bestræbte sig på at få udgivet. Det kan jo virke indlysende nok i betragning af at Norge og Danmark var forenet under samme konge. På den anden side indgik Norges historie ikke i den historie som de kongelige historiografer blev ansat til at skrive. Deres værker omhandler Danmarks historie i snæever forstand. Så Norges position i denne nationalhistoriografiske sammenhæng virker ikke helt afklaret. ${ }^{24}$ Men vi kan notere regeringens interesse i at få publiceret norsk historie, og i de følgende år var det et stadig genkommende argument at de to skrifter burde udgives af patriotiske grunde.

\section{Fredsforhandlingerne i Lübeck}

Tilsyneladende foretog Christian 4. og den danske regering ikke nogen direkte henvendelse til Kirchmann. Men Kirchmann arbejdede ufortrødent på sin udgave og lod også, her i 1620rne, foretage nogle af de afskrifter gennem hvilke Theoderik og Profectio er kendt idag. En af disse afskrifter skiller sig ud fra de andre i flere henseender. Det er en fin renskrift, skrevet af Kirchmann selv. Den omfatter kun Theoderik-teksten - og den indledes med en dedikation til en række højfornemme herrer i deres egenskab af den danske konges fredsforhandlere i Lübeck 1629. Det drejer sig om kansleren Christen Friis, rigsråderne Jakob Ulfeldt og Albret Skeel, den tyske kansler Levin Marskalk og de to holstenere Ditlev og Henrik Rantzau.

\footnotetext{
${ }^{25}$ Jf. Kancelliets Brewbøger 1627-29, s. 39, 20.3.1627: "Miss. til Holger Rosenkrant Jørgensen [Odensegaard] om til Universitetet i København at sende de indices og capitula historia regum Norvigiensium, som M. Johannes Kirchmannus har paataget sig at udgive i Trykken, og i Biblioteket sammesteds lade undersøge, om den samme historia der findes trykt eller skrevet og sende Meddelelse derom. F. T. 3, 979."

${ }^{2}$ Sporgsmålet er diskuteret $\mathrm{i}$ min artikel: Norges plads i den officielle historieskrivning under Christian IV, Nordica Bergensia 7, 1995, s. 55-68.
} 


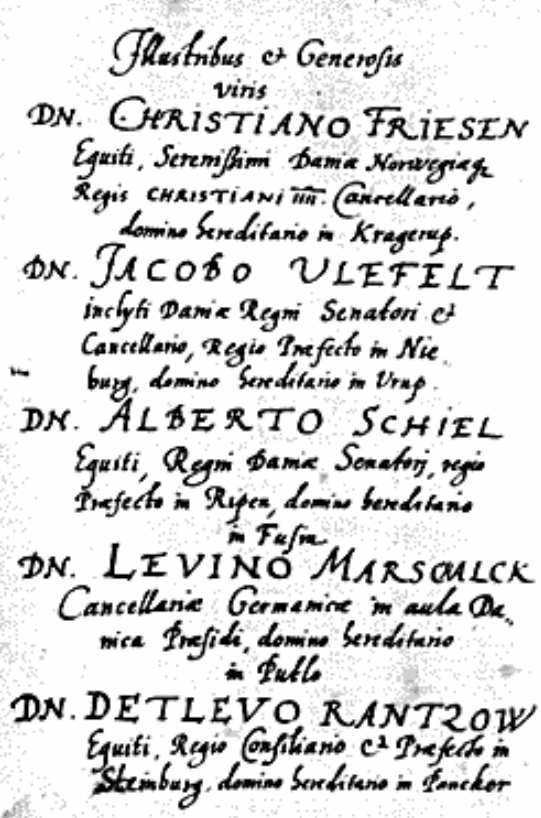

DN. DETLEVO RANTZOW

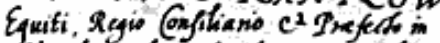
stecinbuy domino berditerio in foncher

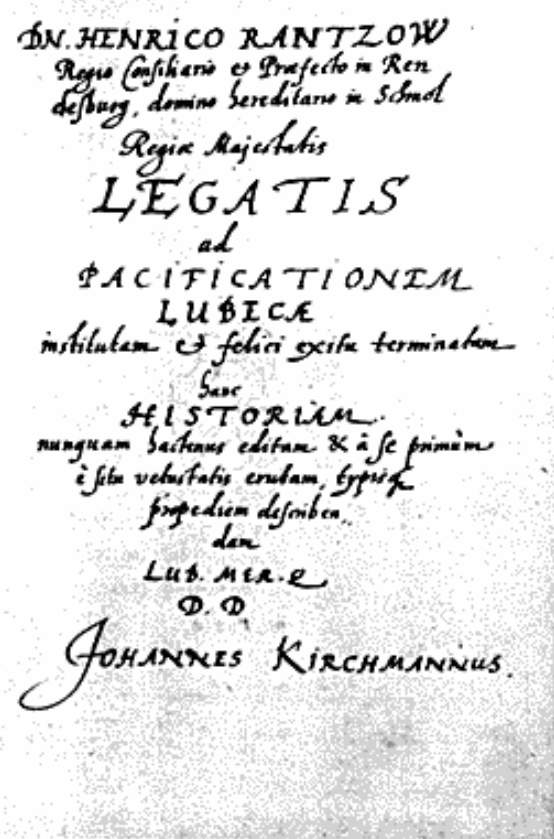

Den indledende dedikation til fredsforhandlerne i Lübeck 1629 i Kirchmanns renskrift af Theoderiks norgeshistorie. (Staatsbibliothek zu Berlin, Preussischer Kulturbesitz, Ms. lat. fol. 356, 1v-2r). Jeg takker biblioteket for tilladelse til reproduktion.

Dette kalligraferede håndskrift - der nu ligger i Berlin Staatsbibliothek - er med andre ord udarbejdet som en gave, en gave som Kirchmann skønnede vardig til at overrækkes de fornemme herrer, den danske konges repræsentanter ved freden i Lübeck. Det er bundet ind i samtidigt lyst pergament og dekoreret med guldsnit, hvad der formentlig skyldes Kirchmann selv og i så fald yderligere understreger at der var tale om en dedikationsgave. Han må have gået ud fra at indholdet - den hidtil ukendte middelalderlige Norgeshistorie - forlenede håndskriftet med særlig prestige. Kirchmanns dedikation til kansleren og de øvrige fredsforhandlere er endnu et udtryk for at national historie regnedes for et anliggende på højeste politiske niveau.

Men håndskriftet er ikke bare en gave. Det er også et led i en publikationsansøgning. Kirchmann havde udset sig denne anledning, fredsforhandlingerne i Lübeck, til at foretage en henvendelse til den dan- 
ske regering om udgivelsesprojektet. Det lykkedes ham da også at få inviteret kansler Friis hjem til sig og få ham til at se og gennemlæse de to småskrifter. Kort efter fredsforhandlingernes slutning skrev han til Friis $\mathrm{og}$ mindede ham om projektet og deres møde fornylig:

"Derfor besluttede jeg at udgive de to småskrifter som du så, og stille dem under dit fornemme navns beskyttelse. Det ene indeholdt altså en historisk beretning om nogle norske konger og var skrevet af en munk ved navn Theoderik for mere end 460 år siden. Det andet berettede om en dansk ekspedition til det hellige land på Kong Knuds tid omkring 1181 [sic]. Eftersom der står meget interessant om Danmarks og Norges gamle historie, forekom det mig at jeg ville yde en god gerning hvis jeg fik draget disse to hidtil uudgivne væerker frem fra det støv og mørke hvor de har ligget som bytte for angrebslystne møl, og sørget for at de kunne blive bevaret for eftertiden."

(Constilueram igilur sub Tuo illustri nomine, in publicum edere, duos istos, quos vidisti libellos quorum alter continebat historiam aliquol Regum Norvagiensium a Theodorico quodam Monacho ante quadringentos, et sexaginta annos conscriptam; alter profectionem Danorum in Terram Sanctam temporibus Canuti Regis circa annum Christi M. C. LXXXI. susceptam. Cum enim plurima in iis inveniantur, qua ad illustrandas Danice Norvagicque antiquitates, faciunt, opere me pretium esse facturum putavi, si eos nunquam antehac editos, et cum tineis blattisque depugnantes e latebris, et situ extraherem, ac posteritati vindicarem.$^{25}$

Her minder han Friis om den nationale - dansk-norske - interesse de to skrifter påkalder sig, og han lover ham endda at dedicere sin udgave til Friis selv. Der er ingen grund til at tvivle på at Friis (som Kirchmann skrev til Meursius et par år senere) tilskyndede ham stærkt til at fă udgaven færdig. Formentlig har han også lovet ham økonomisk støtte, sådan som Kirchmanns barnebarn Bernhard $\mathrm{C}$. Kirchmann hævdede mange år senere i sin udgave af Theoderik og Profectio, der udkom $1684 .{ }^{26}$ Det kalligraferede håndskrift indgik i Kirchmanns fremstød for at sikre sig kanslerens støtte.

${ }^{25}$ Denne passage af det iøvrig ukendte brev er trykt i forordet til Johann Kirchmanns barnebarn Bernhard Kirchmanns udgave af Theoderik og Profectio (note 17), Forord til Laseren, fol. H6r. Om denne udgave senere.

${ }^{26}$ Kirchmann (note 17), Forord til Laeseren, fol. H7v. 
Om fredsforhandlerne faktisk fik håndskriftet overrakt i Lübeck vides ikke. Dedikationen omtaler fredsslutningen som lykkeligt afsluttet - felici exitu terminata - og det er jo muligt at Kirchmann udarbejdede håndskriftet efter deres afrejse og taenkte sig at sende det til København. Dets skabne kendes ikke før det til kom til Berlin Staatsbibliothek i 1850. Her blev det fremdraget i 1936 af den tidligere nævnte Paul Lehmann.

\section{Stephanius}

Friis har altså uden tvivl delt Kirchmanns synspunkt, at dette var en sag af national vigtighed. Det gjorde også Kirchmanns bekendte i Danmark, der i de følgende år igen og igen opfordrede ham til at gennemføre udgivelsen af de to værker. Johannes Meursius, den kongelige historiograf (som Kirchmann havde fảet kontakt med i en anden sag nogle år tidligere) erklærede i 1633: "Jeg beder dig indstændigt om at udgive det. Ikke bare den larde verden, men hele Danmark og Norge vil stå i gæld til dig". ${ }^{27}$ St. J. Stephanius, Meursius' kollega i Sorø som i disse år arbejdede på sin store Saxokommentar, gentog opfordringen året efter i endnu mere entusiastiske vendinger: "Du berømmelige mand, min højt værdsatte ven. Ikke alene har dit brev beredt mig utrolig glæde, for skrevet som det er af en sådan mand er der ikke noget der kunne vare mere opmuntrende. Men med særlig glæede læste jeg den del af dit brev hvori du forklarede at du er i besiddelse af en hăndskreven historisk beretning forfattet af en Theoderik Munk, som i korte trak har skildret de norske kongers livsløb. Jeg vil på det stærkeste opfordre dig til at skynde dig alt hvad du kan med den udgave, ja jeg trygler og beder dig på hele mit fadrelands vegne. Det vil

\footnotetext{
27 "Itaque quantum possum, hortor, uti edas. Beneficium debebit satis, magnum non duntaxat Literaria Respublica, sed $\mathcal{E}$ Dania Vniversa, $\mathcal{E}$ Norvegia: quam utramque in maiorem modum obstringes. Illustris Dus. Cancellarius iam ab aliquo tempore in Cimbria cum Rege agit ... Vbi occasionem eius salutandi nactus fuero, tuis verbis illud faciam. De S. Camuti vita, obituque, item S. Caroli filii ecce habes. Donum est exiguum quidem, sed adfectus in te mei esse illud pignus volo; quodque pretio a se deest, tu benigne aestimando compensabis. Addo effigiem, si hanc tanti arbitraberis: ut praesentem quasi habeas, quem absentem amandum tibi statuis? ..." Brev fra Meursius til Johann Kirchmann, 13.12.1633, Meursius (note 19), XI, no. 718; uddrag i Kirchmann (note 17), Forord til Laseren, og Storm (note 17).
} 
komme til at stå i gæld til dig ved udgivelsen af et sådant mindesmærke som en umild skxebne gennem så mange år har snydt os for." ${ }^{38}$

Men sådan skulle det ikke gå. Indtil sin død i 1643 arbejdede Kirchmann tilsyneladende ufortrødent videre, men realkommenteringen af de to nordiske varker voldte ham vanskeligheder. Hans eget studiefelt var den klassiske oldtid, og den norsk-danske middelalder var åbenbart et ganske nyt felt for ham. Han henvendte sig bl.a. til Stephanius om nogle norrøne ordsprog som indgår i Profectio, og Stephanius lod det gå videre til sin kyndigere ven Ole Worm.

Stephanius selv fik også udbytte af Kirchmanns fund. Han så fx en parallel mellem et af de norrøne ordsprog og en vending hos Saxoog han citerede derfor Profectio-ordsproget i sin store Saxokommentar fra 1645. Ovenikøbet lod han det trykke med runer, for i lighed med Ole Worm anså han runer for den almindeligt brugte skrift i middelalderens norrøne bøger.

Men hans interesse i de to skrifter var ikke begrenset til den slags detailkommentarer. Ad ukendte kanaler fik han selv fat i en afskrift af Kirchmanns håndskrift, indeholdende Theoderik og Profectio. Det skete formodentlig ved årsskiftet 1641-42, for 27. januar 1642 skrev han til Kirchmann og spurgte om ikke det var disse to varker som Kirchmann tidligere havde omtalt for ham. Det håndskrift Stephanius fik fat i er gået tabt. Men han foretog en afskrift, som - i lighed med så mange af hans øvrige efterladenskaber - kom til Sverige og havnede $i$ Uppsala Universitetsbibliotek omkring 1670, hvor det stadig befinder sig. ${ }^{29}$

Stephanius var i denne sidste periode af sit liv - han døde i 1650 beskæftiget med at indsamle materiale til en samlet udgave af værker

\footnotetext{
2\$ "Clarissime Vir, Amice exoptatissime, non solum litere me tua incredibili voluptate perfuderunt, utpote quibus a tanto viro scriptis nihil jucundius accidere potuit: verum magna cum delectatione illam epistole tua partem legi, qua penes te esse significasti manuscriptam historiam cujusdam Theodorici Monachi, qui vitam quorundam Regum Norvegensium breviter descripsit. Ejus ut editionem, quantum in te, matures, serio hortor; imo totius patrie nomine obsecro alque obtestor. Ingenti etenim beneficio eam tibi devincies, edito tam preclaro antiquitatis monumento, quo nos tot annorum interjectu nescio que fatorum invidia fraudari sustinuit." Brev fra Stephanius til Kirchmann, skrevet juli 1634, udg. i Gude (note 17), nr. 249; dele af brevet er trykt i Kirchmann (note 17), Forord til leseren, og i Storm (note 17), s. III.

$\approx$ Theoderik og Profectio er begge anfort i Johannes Hadorphs katalog over håndskrifter doneret af Magnus de la Gardie til universitetsbiblioteket i Uppsala, Apographum donationis testamentarie, Stockholm 1672.
} 
om Danmarks historie, en Scriptores rerum Danicarum, efter model af Andr. Duchesnes udgave af varker om den normanniske historie fra 1619. ${ }^{30}$ Det virker sandsynligt at han foretog sin afskrift af Theoderik og Profectio i den hensigt at inkludere dem i en sådan samling. Da Langebek og Suhm omkring 150 år senere tog tråden op og fik gennemført dette store projekt med deres Scriptores rerum Danicarum-værk, medtog de også både Theoderik og Profectio.

Stephanius vedblev imidlertid også at opfordre Johann Kirchmanns søn til at gøre faderens udgivelsesprojekt færdigt. Efter den gamle Kirchmanns død i 1643 havde sønnen arvet hans materiale og har formodentlig også bragt det videre, men hvori hans indsats faktisk bestod, ved vi ikke. Han var bosat i Slesvig, hvor de gottorpske hertuger residerede, og planlagde i 1650erne at dedicere sin udgave til Hertug Frederik 3. af Gottorp. Efter dennes død udså han sig sønnen Hertug Christian Albrecht som adressat. ${ }^{31}$ Også han havde altså i sinde at henvende sig til magtens spidser med sin udgave af de to små værker om norsk og dansk middelalderhistorie. Men han har altså tilsyneladende ikke, som sin far, villet dedicere sin udgave til en dansker og dermed alludere til teksternes nationalhistoriske indhold. Og dog havde han måske, som sønnen faktisk senere gjorde (se ndf.), netop tænkt sig at begrunde dedikationen nationalt, nemlig med de gottorpske hertugers arvekrav til Norge, som gik tilbage til Christian 3.s yngre brødre, hertugerne Hans og Adolf af Slesvig og Holsten. Det dansk-gottorpske forhold var yderst spændt $\mathrm{i}$ anden halvdel af det 17.årh. Gottorp støttede den svenske arvefjende, og i 1658, i forbindelse med Roskildefreden, kunne Frederik 3. af Gottorp løsrive sig fra lensforholdet til Danmark. Johann Kirchmann d.y.s planer om at dedicere de to værker om dansk-norsk historie til den gottorpske hertug afspejler de samtidige politiske magtforhold.

${ }^{\text {so }}$ Herom s. 199 og 234f. i H.F. Rørdam: Den kongelige Historiograf Steffen Hansen Stephanius, Historiske Samlinger og Studier, I, 1891, s. 1-74 og 193-275.

"Johann Kirchmann d.y.s dedikationsplaner kendes gennem sønnen Bernhards udkast til forord til sin udgave, henvendt til hertug Christian Albrecht og dateret 1.5.1680 (indlagt $\mathrm{i}$ håndskriftet Thott 15414 to, Kgl. Bibl.): "Destinaverat hic [nl. Johann Kirchmann d.y.] ineditum hactenus scriptum ... in publicum producere: et primo quidem Augusto Parenti Tuo, aterna memoric PRINCIPI, sub cuius felici regimine, in hoc municipio Tuo, iam ab anno MDCXL fortunarum suarum sedem, et domicilium is eligerat: inde Divo Parente Tuo rebus mortalium evocato, ubi iam Te PRINCEPS OPTATISSIME, nostra tutele fata admovissent, nomini Tuo SERENISSIMO illud ipsum inscribere. " 


\section{Bernhard Kirchmanns udgave og dens adressater}

Men det blev ikke til noget, og heller ikke i Danmark var der tilsyneladende nogen der skankede skrifterne en tanke efter Stephanius' død i 1650. I det hele taget kan man notere allerede ved kansler Christen Friis' død i 1639 at den markante historiografiske aktivitet der havde præget 1620rne og 1630rne aftog. Dog blev Stephanius faktisk udnæunt til Meursius' efterfølger som kongelig historiograf efter Meursius' død, ligeledes i 1639. Men da han så også var væk, var der åbenbart ikke meget incitament til nye historiografiske initiativer - og heller ikke til at holde liv i gamle Kirchmanns udgivelsesprojekt.

Nyt skub i sagen kom der først da Johann Kirchmann d.y.s søn, Bernhard Kirchmann, i slutningen af 1670 erne under et ophold i Amsterdam blev kontaktet af en boghandler (librarius), der vidste at hans familie var i besiddelse af de to skrifter og bad ham sørge for at gøre udgivelsen faerdig og trykke dem hos ham. Hvis vi kan stole på denne historie (som vi har fra et af Bernhard Kirchmanns forord ${ }^{32}$ ), synes denne trykker at nære kommercielle forventninger til udgivelsen. Bernhard Kirchmann påtog sig da opgaven, og resultatet blev førsteudgaven af Theoderik og Profectio, der udkom i 1684 i Amsterdam.

Heller ikke Bernhard Kirchmann valgte sig danske adressater, i hvert fald ikke i første omgang. Også han var bosat i Slesvig. I 1680 skrev han udkast til en dedikation til Hertug Christen Albrecht af Gottorp (1641-94, hertug 1659), samt en kortere dedikation greldende Profectio til hertugens kansler Martin Bozkeln. Han begrundede sit valg af adressat med at hans farfar havde fundet håndskriftet i nærheden af Christen Albrechts domæne, og at dette håndskrift i mange år havde opholdt sig hos Bernhards far, den yngre Johann Kirchmann, $i$ hertugens domæne. Men han sørgede også for, som ovenfor antydet, at knytte skrifternes nationalhistoriske indhold til adressaten: Dette er et skrift om de gamle norske konger, forklarer han, og hvad er da mere passende end at dedicere det til den gottorpske hertug som fører titlen arving til Norge? ${ }^{33}$

\footnotetext{
32 "... et forte eodem tempore, librarius Amstelodamensis, qui sciebat, penes nos esse scripta duo historica vetusta, ex Clarissimi avi cura et hereditate, alterum de Regibus antiquis Norvagia: alterum de profectione Danorum in terram sanctam, hactenus inedita: dum ob domestica negotia in Belgio proxime versarer, instantissime flagitaret, ut eadem opera, et typo suo describenda et evulganda, tramitterem. "Bernhard Kirchmann (note 31).

ss "Istorum nomina et Leones inter titulos Tuos et insignia gentilitia, ipse Norvagia non indignus heres, prafers." Bernhard Kirchmann (note 31 ).
} 
Bernhard skiftede imidlertid mening, og i oktober 1683 udfærdigede han to nye dedikationsbreve, og det blev dem der blev trykt. Her $i$ anden omgang vendte han tilbage til farfaderens tanke om en dansk adressat. Faktisk forenede han i en vis forstand farfaderens og faderens dedikationsplaner og dedicerede udgaven både til den danske og den gottorpske kronprins, der begge hed Frederik. Dedikationsbrevet til den danske kronprins hylder ham som normannernes efterkommer og dermed som en naturlig modtager af dette skrift, mens det andet dedikationsbrev, til den gottorpske kronprins, hentyder til den samtidige politiske spænding mellem Danmark og Gottorp og anmoder de to Frederik'er, med et spil på deres faelles navn, om at forbedre forholdet.

Hvad der har fået ham til at ændre adressat kan man jo kun gxtte på. Måske så han det som en mulighed for at komme til at argumentere for fred gennem denne dobbeltdedikation. Måske var det samme slags overvejelse som i sin tid havde fået hans farfar til at satse på den danske kansler - at dette her var dansk-norsk historie, og derfor var en dansk adressat passende. Men det er også fristende at se skiftet som en pragmatisk vurdering af det andrede styrkeforhold. Mens den gottorpske hertug efter freden i Fontainebleau i 1579 syntes styrket - den danske konge måtte tilbagegive erobrede områder, og hertugen kunne vende tilbage til Gottorp efter fem års ophold i Hamburg - steg det danske pres i Holsten i begyndelsen af 1680erne, og i 1684, altså kort efter at Bernhard skrev sit nye forord (1. oktober 1683), kunne den danske konge indlemme den gottorpske del af Slesvig (hvad han dog måtte opgive igen få år senere). Det kan i hvert fald konstateres at også sønnesønnen valgte at adressere de to norges- og danmarkshistoriske tekster til de øverste magthavere.

\section{4-udgavens modtagelse}

Med udgaven 1684 lykkedes det altså over 60 år efter Johann Kirchmanns fund at få de to tekster udgivet i trykt form. Vi er nu fremme i en tid hvor den larde offentlighed underrettedes om nyudgivelser gennem anmeldelser og omtaler i tidsskriftlignende publikationer, og udgivelsen af Theoderik og Profectio blev da også i løbet af de næste par år bekendtgjort for den europæiske lærde offentlighed.

I Danmark-Norge viste det sig snart at gamle Kirchmann havde haft ret i sin formodning om at skrifterne ville vakke opsigt. Således læste Thomas Bartholin d.y. opmærksomt i Theoderik i forbindelse med sit 
store vark om danernes dødsforagt fra 1689, Antiquitatum Danicarum de Causis Contempte a Danis adhuc gentilibus mortis libri tres, der altså udkom allerede fem år efter Bernhard Kirchmanns udgave. I de følgende år arbejdede Thormod Thorfaus på sin store norgeshistorie, på opdrag af den danske konge. Også han høstede meget stof i de to småskrifter. Endda kunne han udnytte Profectio til at komme med en hvas korrektion af Saxos fjendtlige beskrivelse af den norske kong Sverre (1182-1202). I Profectio, forklarer han, kan man tværtimod se at Sverre var en mild, storsindet, gavmild monark - stik imod Saxos løgne. Her indgår Profectio altså i en specifik norsk argumentation, polemisk vendt mod den danske tradition. ${ }^{34}$

De to skrifter vakte opsigt - men selve udgaven høstede ikke enstemmig anerkendelse. Ihvertfald var den islandske historiker og filolog Árni Magnússon (1663-1730) så utilfreds at han satte sig for at foranstalte en ny og bedre udgave. Så han lagde vejen om ad Lübeck i 1696 for selv at tage det middelalderlige håndskrift i øjesyn som gamle Kirchmann havde fundet, for på det grundlag at kunne foretage en nyudgivelse. Men her blev han skuffet, for håndskriftet var ikke længere i bibliotekets eje. Faktisk kan man se af et katalog over Lübeckbibliotekets bestand der blev udarbejdet 1689 - det første siden Kirchmanns fra 1622 - at håndskriftet heller ikke da fandtes i biblioteket. Sandsynligvis har den zeldre Johann Kirchmann taget håndskriftet hjem, da han sad og forberedte sin udgave. Så er det gået $\mathrm{i}$ arv til sønnen, den yngre Johann, og Bernhard skriver faktisk $\mathrm{i}$ et af sine forord at håndskriftet i mange år lå hos hans far. ${ }^{35}$ Hvad der så er sket med det, vides ikke. Der er steder i Bernhards udgave 1684 der tyder på at han ikke havde adgang til det middelalderlige håndskrift.

Árni Magnússon opgav dog ikke så let. Via en bekendt, A. Kellinghusen i Hamburg, fik han kontakt med Bernhard Kirchmann, der i mellemtiden var blevet embedsmand i Husum, og bad ham om at få lov til at låne det håndskrift som hans farfar havde ladet udarbejde eller endnu bedre, som han optimistisk tilføjede, det middelalderlige

\footnotetext{
34 Thormodus Torfaus: Historia Rerum Norvegicarum, 1711. Afsnittet om Sverres personlighed står i del IV, kap. 26.

ss "... inter regiminis tui limites, Parenti meo Optimo avo Clarissimo cognomini, inter librorum scrinia iam multis annis fuit servatum." Bernhard Kirchmann (note 31).
} 
håndskrift selv. ${ }^{36}$ Det er formodentlig denne forespørgsel der førte til at Árni faktisk fik fat i en afskrift af Theoderik og Profectio. Den - eller en afskrift som Árni derpå lod tage af den - ligger nu i den arnamagnæanske samling. Han kendte også til Stephanius' afskrift som var kommet til Uppsala og fik gennem svenske bekendte foretaget nogle check af læsemåder heri.

Árni Magnússon fik dog aldrig gennemført sin udgivelsesplan. Men det blev hans håndskrift som kom til at danne grundlaget for andenudgaven af Theoderik og Profectio, nemlig Suhms udgave, der kom i 1783 i storværket Scriptores rerum Danicarum, bind V.

På det tidspunkt var norsk nationalhistorie stadig en del af den danske. Men 100 år senere, i 1880, sørgede den norske historiker Gustav Storm som næunt for at Norge nu fik sin nationale udgave af norske middelalderværker på latin, Monumenta historica Norvegice. Her indtager Theoderiks værk en fornem position. Som den tidligste, og den eneste fuldstændigt overleverede latinske norgeshistorie, optræder det som det første vark i bindet.

Profectio regnedes dog stadig som dansk og en ny udgave af dette skrift blev, som også tidligere omtalt, foretaget af den danske filolog M.Cl. Gertz og indlemmet i hans udgave af Scriptores minores II i 1922. Siden er dog også Profectio blevet norsk - der er nu som sagt almindelig enighed om at det er skrevet af en norsk præmonstratensermunk - så nu er både Theoderik og Profectio med i det tekstkorpus som for tiden udgives som Norges ældste latinlitteratur. ${ }^{37}$

Men at de to små middelaldervarker overhovedet er overleveret skyldes at de - formodentlig engang i begyndelsen af det 13. årh. i et dansk eller norsk skriptorium - blev tilføjet i slutningen af et Josephus-håndskrift.

"Árni's brev til Kellinghusen, 1.6.1699, er trykt i Arne Magnussons private Brevveksling, 1920, s. 269-270. Det er her anført, at Kellinghusens derpå følgende henvendelse til Bernhard Kirchmann er nedskrevet på indersiden af bindet og dateret juli 1699 .

${ }^{37}$ I regi af det norske forskningsråds Antikkprogram har en udgivergruppe siden 1997 arbejdet på nye udgaver af de fire centrale historiske varker på latin fra norsk middelalder. Theoderiks Norgeshistorie udgives af prof. Egil Kraggerud (Oslo), Historia Norwegie (skr. o. 1150) vil udkomme i en udgave ved nu afdøde forskningsstipendiat Inger Ekrem (Oslo)og prof. Lars Boje Mortensen (Bergen), Passio Olavi (den hellige Olavs liv og mirakler, skr. o. 1180) udgives af prof. Lars Boje Mortensen (Bergen), og endelig vil korstogsberetningen Profectio Danorum komme i en udgave ved Karen Skovgaard-Petersen. 
SUMMARY

KAREN SKOVGAARD-PETERSEN: A manuscript discovery in Lübeck $c$. 1620 - on the transmission of two Norwegian literary momuments

The article traces the common manuscript history of two small Norwegian historical narratives from the last decades of the twelfth century with a focus on the varying motives for which they have been studied in the course of time. The two works are Theodericus Monachus's history of Norway written c. 1180, and an anonymous account of a Danish-Norwegian expedition to the Holy Land in 1191-92 written c. 1200, the De Profectione Danorum.

The two works were unknown to the learned world, when Johann Kirchmann, leader of the newly founded Stadtbibliothek in Lübeck, around 1620 found a medieval parchment codex among the books delivered from the town council to the library. This manuscript - which disappeared later in the seventeenth century - contained Josephus's Bellum Judaicum, followed by the two Norwegian chronicles and a third text. It was probably written not long after 1200 in Denmark or Norway. It seems likely that the manuscript was brought to Lübeck in the early 1460 s by the papal legate Marinus de Fregeno, where it was confiscated. Marinus had been in Scandinavia to collect money and, in the spirit of Renaissance humanism, to look for manuscripts containing classical texts. No doubt it was the Josephus-text that caught his eye.

To Johann Kirchmann, however, the sensation lay in the two hitherto unknown Scandinavian histories. He started preparing an edition of both of them, establishing contacts with Danish historians, among them Stephanius who also seems to have planned to publish the two texts. Kirchmann even attracted the interest of the DanishNorwegian government, which promised to support his edition financially. But it was to be Kirchmann's grandson Bernhard who published the editio princeps as late as $\mathbf{1 6 8 4}$. He also selected dedicatees on the highest political level. Not content with the philological quality of the edition, however, Árni Magnusson around 1700 began to prepare a new edition. The medieval manuscript being lost, the two texts are known today through transcriptions made in connection with the editorial efforts of the Kirchmann family, Stephanius, and Árni Magnusson together with B. Kirchmann's edition.

Arni Magnusson's plan did not materialize until P.F. Suhm included both texts in the Scriptores rerum Danicarum vol. V (1783). By that time Norway was still united with Denmark. When Gustav Storm in 1880 published his Monumenta historica Norzegiae, he only included Theoderik assuming that the Profectio was a Danish work. It is now commonly regarded as being the work of a Norwegian author, and the text forms part of the corpus of Norwegian medieval Latin texts which is currently being published. 